\title{
The Role of Electricity in Sustainable Energy Supply
}

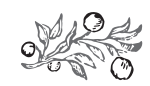

\section{Summary}

Ever since the dawn of history, humans have always needed energy, used it in a gradually growing number of fields and found new forms to meet their ever increasing demand. It is no exaggeration to claim that in the absence of energy, the very means of subsistence would cease to exist for today's urbanised society. Nothing would function without electricity: neither the control systems run by IT tools, nor the core and auxiliary equipment of the fundamental supply and care systems. In the absence of electricity, water and natural gas supply would stop, ventilation systems would become inoperable, transport and traffic would shut down, and in the absence of illumination, everything would go dark, buildings would not be heated and cooled, both industrial and agricultural production would stop, the supply of drinking water and food would become unfeasible, communication and security systems would become inoperable, and law enforcement could not attend to their duties either. In other words, the absence of energy would lead to an economic and social disaster. After a description of climate change, the article gives a glimpse of the energy policy of the European Union, and outlines the main pillars of Hungary's new energy strategy.

Journal of Economic Literature (JEL) codes: O13, P28, Q54

Keywords: energy, sustainable development, carbon dioxide, environmental protection, climate change

Ferenc Molnár, PhD student, Óbuda University, Doctoral School on Safety and Security Sciences, Head of Sustainable Generation Team, MVM Hungarian Electricity Private Limited Company (fmolnar@mvm.hu). 


\section{Ferenc Molnár: The Role of Electricity in Sustainable Energy Supply}

\section{ENERGY APPETITE AND GLOBAL WARMING}

Today's population of nearly 8 billion consumes multiple times the maximum amount of energy needed for sustainable development. Humanity, rapidly growing in number, is depleting the Earth's energy supply and destroying its natural environment by a ruthless use of energy. If the current trend of "development" in civilisation is not reversed, in the foreseeable future we will eliminate the preconditions of survival for the future generations. It is an apt commonplace that we do not own the Earth; we have only borrowed it from our grandchildren. The damages caused by civilisation include the myriad of diseases and human deaths caused by climate change and pollution, resulting from global warming. The availability of energy is the driving force behind economic development. According to Elkington, sustainable development is based on the optimisation of environmental, economic and social sustainability for companies (Borzán and Szekeres, 2017). For the sake of maximum short-term economic growth, the individual economic operators disregard the environmental aspects that ensure long-term living conditions. This can only be offset in nominal terms by certain processes, such as integrated urban development plans (Pintér, 2015).

The 28 countries of the EU have a population of over 512 million. As the population grows, the use of primary energy will also increase, but energy consumption will increase at a much faster pace. In retrospect, according to a survey in $2000,16 \%$ of the population was already using $80 \%$ of the total amount of energy consumed. According to research conducted at the University of California, the largest emitters of carbon dioxide are transport, with $49 \%$ and the power sector with $30 \%$ (Hejazi, 2017). According to the International Energy Agency, in 1980 the Earth's population consumed nearly 7300 million tonnes of oil equivalent (Mtoe). This value increased by more than two-thirds in 2008 to 12,300 Mtoe (IEA, 2010). Already between 1980 and 2008, there was a strong upward trend in primary energy consumption.

By 2040, the energy demand of the Earth's inhabitants will increase by $25 \%$ of the value of 2017. Without energy efficiency measures, this would double the amount of energy consumed in 2017. India's energy consumption could grow nearly double, while China's consumption could increase by nearly one-fifth over the same period.

In the context of sustainable development, the rising share of electricity in final energy use will play an increasingly important role in maintaining clean air, reducing pollution and improving climate parameters. Total electricity generation is projected to reach $45 \%$ or 37000 TWh in 2040 .

The share of renewable energy sources will almost triple to $66 \%$. Solar and wind farms are expected to see the greatest increase in energy production. By 2025, more than $80 \%$ of new capacity expansion is projected to come from renewable sources.

The average carbon intensity of electricity production is expected to decrease globally. From the current 500 grams of $\mathrm{CO}_{2}$ per kilowatt hour, the target for 2040 will be reduced to about 70 grams of $\mathrm{CO}_{2}$ per $\mathrm{kWh}$. This is mainly due to the increasing share of electricity in final energy use. 
Chart 1: Electricity generation and carbon intensity in sustainable development

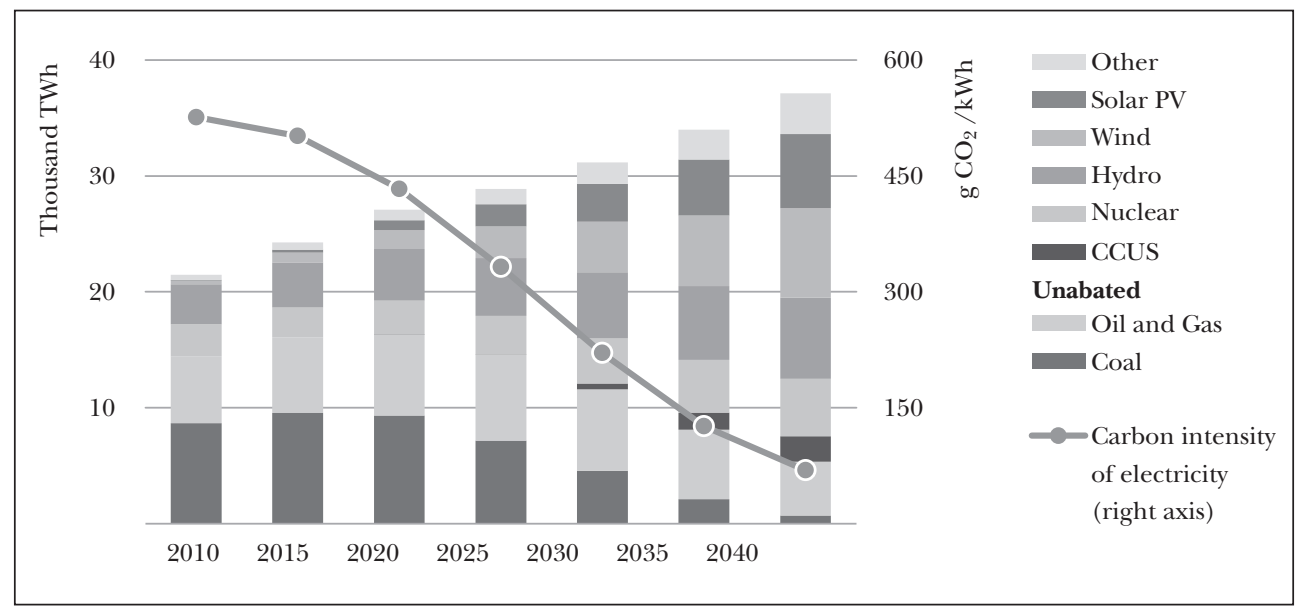

Source: IEA, 2018, p. 93

Chart 2: Global primary energy demand by fuel and energy-related CO2 emissions by scenarios

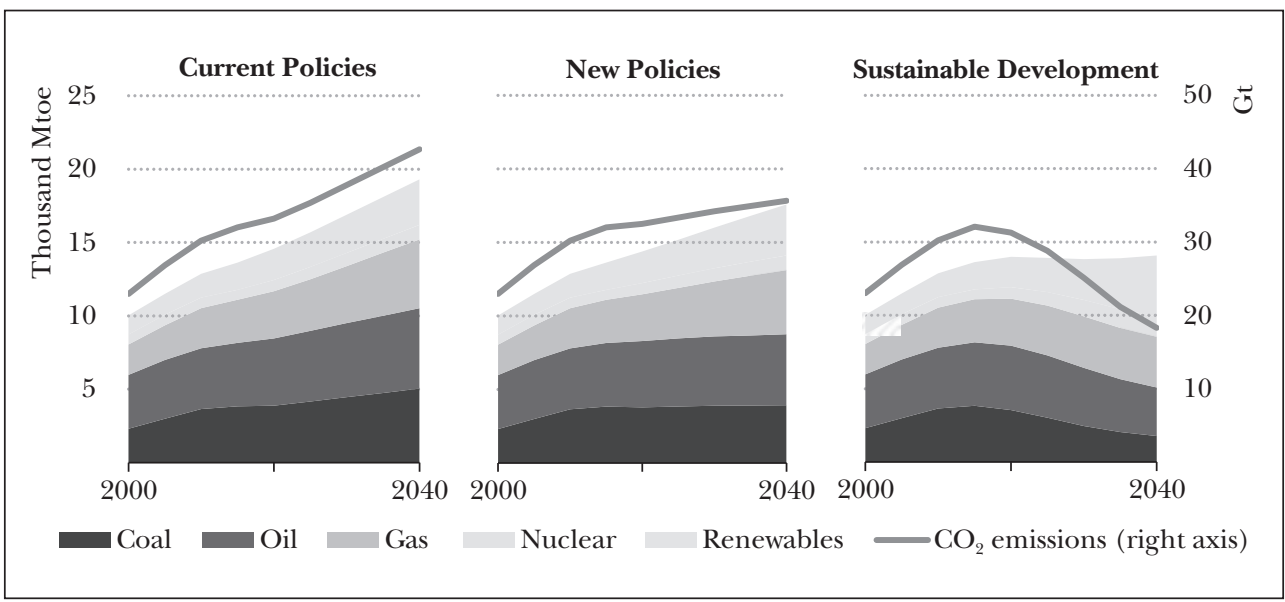

Source: IEA, 2017, p. 78

It follows from these quantities that the Earth's energy reserves are being exploited at a disastrous rate. More than $70 \%$ of the energy consumed comes from fossil fuels. The proportion of nuclear and renewable production is a fraction of that of fossilbased applications.

Another, even more serious impact on life on our planet is the acceleration of global warming and the consequent irreversible climate change.

Most energy sources contribute to climate change. There is a worldwide trend of increasing use of fossil fuels in proportion to the increase in energy consumption. Of course, this will also increase the amount of greenhouse gases released into the Earth's 
atmosphere and the amount of gases that are accumulated there. Energy-related carbon emissions have increased from 18.7 billion tonnes in 1980 to 29.4 billion tonnes in 2008 (IEA, 2010). In 2017, carbon dioxide emissions from energy use amounted to 32.581 billion tonnes (IEA, 2018). In 2007, the populations of developed and developing countries had a share of 4.5 toe and 0.7 toe per capita on average, respectively (Tashimo and Matsui, 2008). Most of the energy used today still comes from the burning of fossil fuels, which is also the main source of carbon dioxide emissions.

The global energy trend is driven by the free market, the uncertainties of the political and financial systems, and the impact of the media on users who lack knowledge. Despite the difficulties of long-term energy planning, it is clear that coal-based electricity production will continue to play a leading role in the world outside Europe. In addition to coal, the use of natural gas will continue to be the dominant fossil fuel (Járosi, 2018).

The greenhouse effect is a natural process that provides the atmospheric temperature needed for the Earth's current wildlife. A smaller portion of the sun's rays are reflected back into space, reaching the Earth's atmosphere. Most of the energy coming from the sun enters the atmosphere, warming the surface of our planet.

The temperature required for life is provided by the accumulation of greenhouse gases (GHGs) in the atmosphere of the Earth, by reflecting off, i.e. trapping, a portion of the amount of heat that leaves the atmosphere.

Greenhouse gases include water vapour, carbon dioxide, methane, nitrous oxide, ozone and some artificial chemicals such as chlorofluorocarbons (CFCs). Human activity increases the atmospheric concentration of GHGs, which increases the greenhouse effect, thus accelerating the warming of the atmosphere.

The most important such human interventions are the burning of fossil fuels (coal, oil and natural gas), agricultural activities and deforestation. The main source of greenhouse gases is the combustion process. Of the gases produced by combustion, carbon dioxide is the largest contributor to our environment. The amount of carbon sequestrated over hundreds of millions of years returns to the natural environment in a concentrated form within just a few centuries. This situation is exacerbated by the fact that 300 hectares of rainforests are lost per hour due to humanity's over-consumption and the pursuit of profit.

The natural environment on Earth is thus exposed to numerous dangers and is highly vulnerable. The most devastating process is the global warming of the Earth's atmosphere. Climate change is a direct consequence of global warming. The greatest challenge the human race is facing in the 21st century is addressing the consequences of climate change. The measurements performed in recent years show that the Earth's average temperature has risen by more than 2.5 degrees Celsius. If this trend continues, the number of starving humans will increase by more than eighty million, and more than a quarter of all the mammal species and more than a tenth of the bird species will completely disappear (Hejazi, 2017).

The most obvious solution for reducing carbon dioxide emissions is to increase the utilisation ratio of carbon-free energy sources used in power generation. The use 
of nuclear and renewable energy sources should reduce the proportion of fossil fuels. The carbon dioxide emission of the entire nuclear, solar and wind energy chain is the same, i.e.2-6 gr / kWh. This includes the manufacturing, construction, operation and maintenance processes. Electricity offers the potential to increase energy efficiency through the use of a high degree of automation and smart solutions (Hejazi, 2017).

\section{A glance at THE EuROPEAN UNiON}

The European Union's climate protection measures included drafting Directive 2009/28/EC. The directive sets out the exact figures for each Member State's contribution to the use of renewable energies. This means that by 2020 an average of $20 \%$ of the EU's gross energy consumption should come from renewable energy sources, including $10 \%$ in the transport sector. The $20 \%$ average is the average of the individual commitments by all Member States.

In 2016, the European Commission compiled the PRIMES (Price-Induced Market Equilibrium System) energy system model, which aims to support Clean Energy for All Europeans, also known as the Winter Impact Study (European Commission, 2016a). The study analyses the relationships between decarbonisation activities up to 2030, but also provides an outlook to 2050 (European Commission, 2016b). It examines whether or not the competitiveness of the European Union can be maintained in the context of the changing energy market conditions as it is moving towards a low-carbon economy. Electricity generation, energy efficiency and renewable energy are the pillars of transition to a clean energy future (European Council, 2014). The ETS (Emissions Trading System) serves to decarbonise the European Union's energy system by reinforcing the impact of policy measures.

The interaction of synergies was performed by a quantitative analysis using sophisticated methods. The Impact Assessment is an accompanying document to the programme packages prepared for the institutions of the European Union, and relies on two policy scenarios: EUCO27 and EUCO30 (the European Council's two scenarios for achieving $27 \%$ and $30 \%$ energy efficiency, respectively). It is a review of electricity market rules and risks. EUCO33; 35; 40 (the European Council's 33\%; 35\% and 40\% energy efficiency scenarios) set even more ambitious targets to be achieved by 2030 . The EUCO3030 scenario includes plans for an increased ratio of renewable energies in the EU energy mix.

Each scenario aims to help the European Union develop its energy strategy for 2030 and set goals and actions for achieving a low-carbon economy by 2050. All the decarbonisation scenarios are in line with the 2015 Paris Convention, which foresees more than $80 \%$ reduction in greenhouse gas emissions by 2050 compared to 1990 emission levels.

Each scenario confirms, in numerical terms, that carbon market pricing has a clear carbon impact and contributes to the development of renewable technologies.

The various energy efficiency scenarios of the EU endeavour to reduce energy consumption. 
Chart 3: Energy demand in the EU28 according to different scenarios

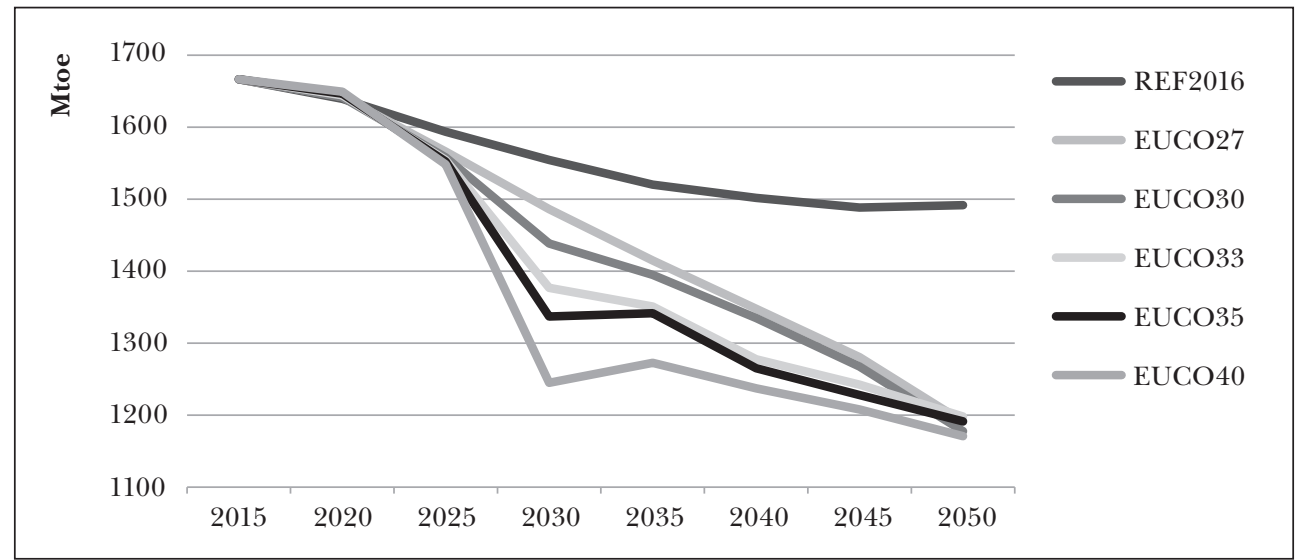

Source: Capros et al., 2018

The share of electricity in the decreasing final energy consumption is increasing.

Chart 4: The ratio of final energy demand (Mtoe) (a) to electricity in EU28 (b)

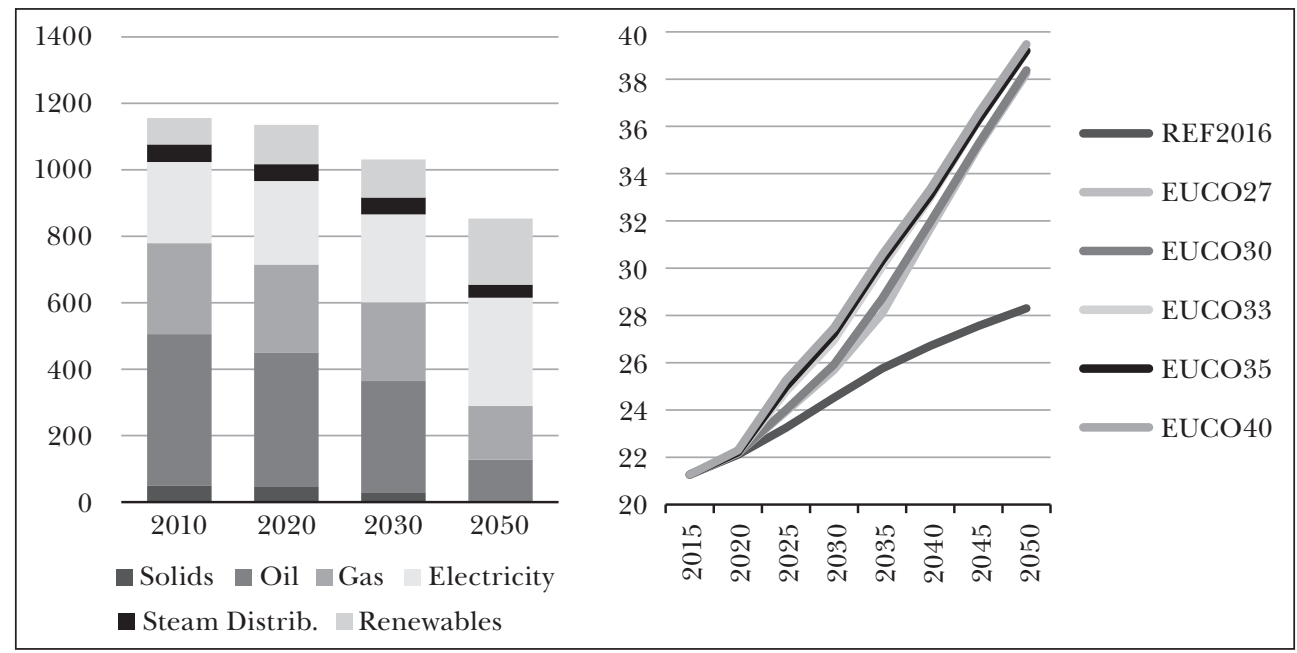

Source: Capros et al., 2018

Among the countries of the European Union, Germany is the flagship for the use of renewable resources. The leadership of the country intends to further strengthen this position. At present, it has nearly 106,000 MWp of wind and solar power installed capacity. By 2030, further significant expansion of solar energy sources producing in sunny periods is planned. The diagram of power generation structure illustrates appreciation in the role of regulatory capacities as a result of increase in the share of weather-dependent renewables by 2030 . The hectic avail- 
ability of solar and wind energy is for the most part planned to be tailored to the needs of consumers by gas turbines and imported energy. Regrettably, the GHGfree, economically viable source of clean energy as a basic nuclear power plant is missing from the production structure projected for 2030. Germany has already become incapable of meeting its commitments made to the European Union as it has cut its nuclear production, and so its energy and economic policies need urgent reconsideration.

Chart 5: Germany's daily electrical load curve for 2017 and projected for 2030

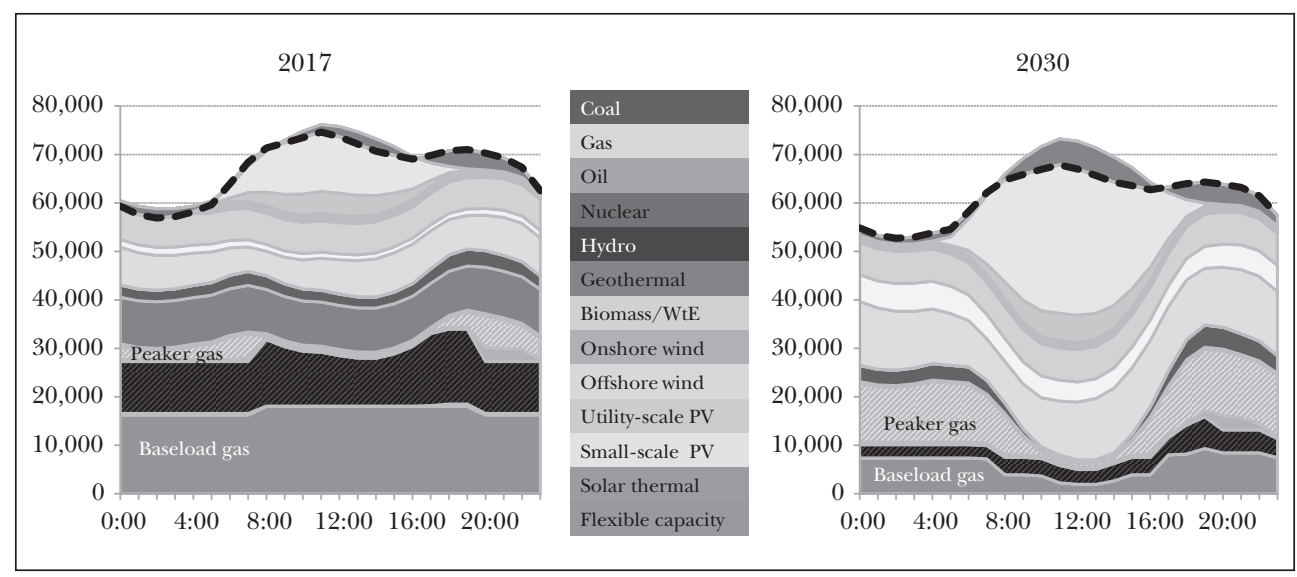

Source: Bloomberg, 2017

If the EU Member States shut down their existing nuclear power plants, the fossil fuel power plants that replace them would release 700 million tonnes of additional carbon dioxide into our Earth's atmosphere every year (Hejazi, 2017).

Reduction in the EU's energy-related carbon dioxide emission is primarily expected in the energy supply sector: in 2050 only the transport sector is expected to use oil. The use of natural gas in the industry and in the energy consumption of buildings may remain to some extent. The sectors covered by the ETS (Emission Trading System) are expected to have a much larger emission reduction effect than the sectors outside the ETS (Capros et al., 2018).

The feasibility of predictions is worth examining in the light of current global trends. The factual data registered globally up to 2017 shows an increase in carbon dioxide emissions in proportion to the steady increase in energy demand.

British Petrol's (BP) Energy Outlook also forecasts reduction in final primary energy consumption in its prediction for the European Union for the period up to 2040. The forecast expects a significant increase in the share of renewables and a drastic cut in the use of carbon-based energy, which also contributes to Europe's depletion of its coal reserves. In addition to transport, oil consumption is expected to remain significant in the chemical industry, but a downward trend can be brought about by increased energy efficiency and e-mobility (British Petrol, 2019). 
Chart 6: Greenhouse gas emission targets for the EU28 according to the EUCO27 scenario

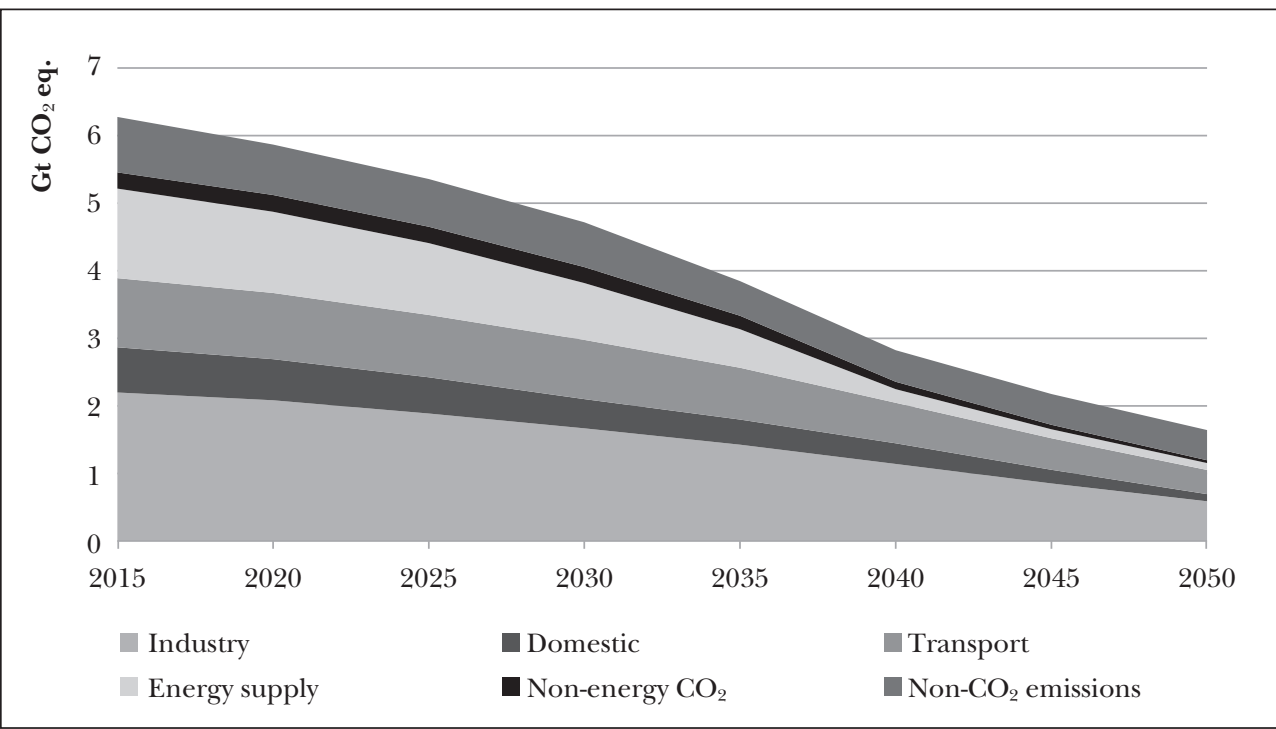

Source: Capros et al., 2018

Chart 7: Expected evolution of primary energy needs up to 2040, Gtoe, EU Member States

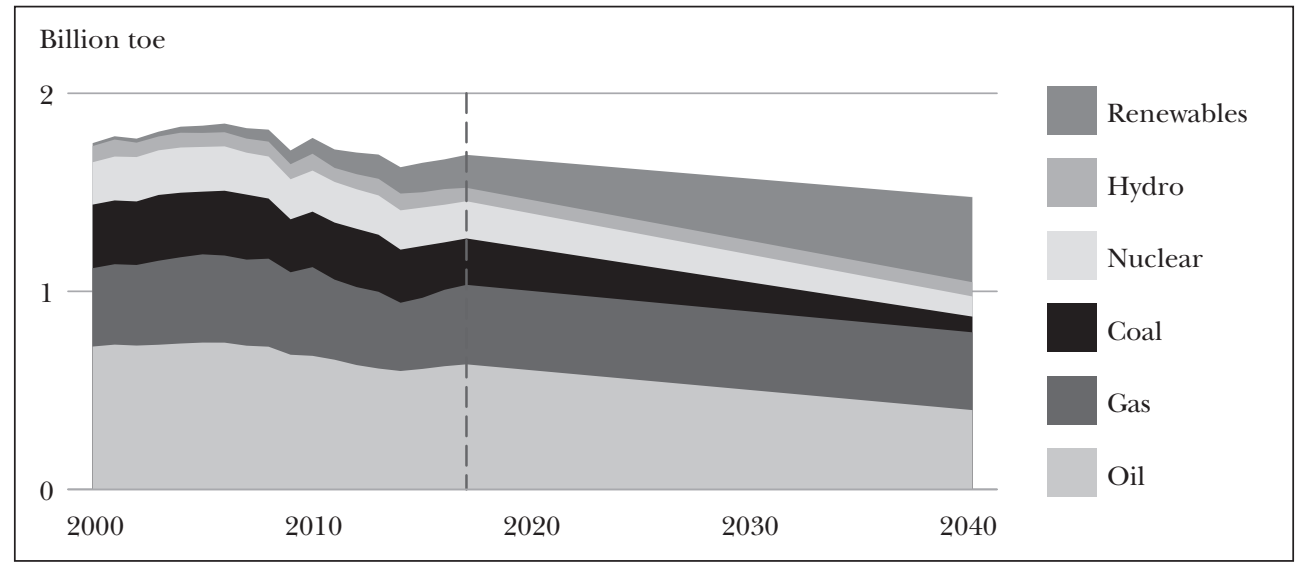

Source: British Petrol, 2019

The expected share of electricity generation also shows significant restructuring by 2040 . The growth of renewables is unstoppable. Unfortunately, the ratios of hydropower and nuclear sources, which produce clean energy, are expected to decrease in the primary energy mix. The regulation of renewables and nuclear substitution are also expected to generate additional carbon emissions. The ratio of carbon will decrease, but it will still have a significant impact on atmospheric pollution in terms of climate protection (British Petrol, 2019). 
Chart 8: The expected share of electricity production in electricity generation by 2040

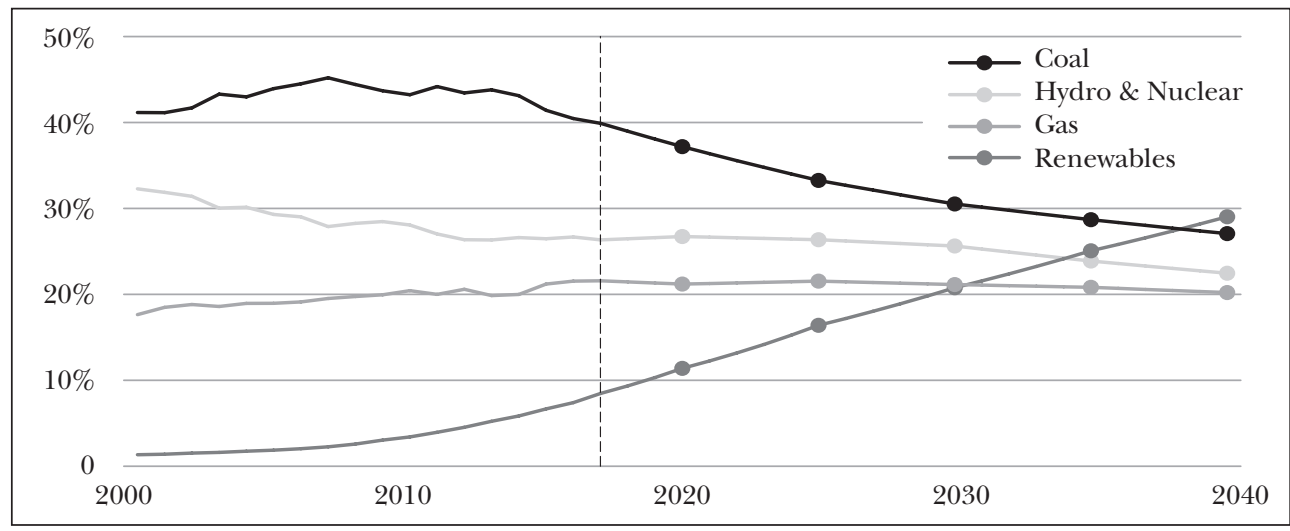

Source: British Petrol, 2019

\section{HUNGARY'S NEW ENERGY STRATEGY CONGEPT}

In October 2018, Hungarian Parliament adopted a National Energy and Climate Plan (Ministry for Innovation and Technology, 2018), which is in agreement with the Paris Agreement. In December 2018, the government adopted the concept of a new energy strategy that integrates the adopted climate and energy policy. The energy sector is undergoing a radical change worldwide. In this accelerating transition, the policy intends to create a consumer and climate-friendly energy sector in Hungary. Energy use is responsible for more than $70 \%$ of greenhouse gas emissions, both internationally and domestically. The competent ministry estimates that one way to reduce the need for oil and gas imports is to use renewable energies and save energy. The government envisages the 3D principle for the development of the electricity sector: decarbonisation of the electricity sector, decentralisation of household and industrial renewable generation and digitisation, or the spread of digital technologies.

The targets set by European Union's technical committees include a $40 \%$ emission reduction target at an EU level by 2030 and $80 \%$ by 2050 compared to 1990 emission levels. The second National Climate Change Strategy, released in 2018, requires the reduction of emission in Hungary by at least $52 \%$ and at most $85 \%$ by 2030 , compared to 1990 emission levels. The $40 \%$ reduction set in the relevant EU requirements means that Hungary will emit maximum 56.28 million tonnes of carbon dioxide per year in 2030. In 2017, Hungary's emission was 64.44 million tonnes of carbon dioxide (Ministry for Innovation and Technology, 2018).

Hungary's energy policy is based on the European Union's energy strategy objectives. However, its objectives and related measures are shaped by the characteristics of domestic energy producers and the country's economic policy without excessive dependence on the European Union. Thanks to the development of nuclear and renewable energy capacities, Hungary will be able to reach $90 \%$ carbon-free electricity production by 2030. However, achieving full domestic carbon neutrality can only be 
achieved if the competitiveness of the Hungarian economy and the overhead costs of Hungarian families are also taken into account (Portfolio, 2019.)

Chart 9: Distribution of domestic gross electricity consumption in 2018

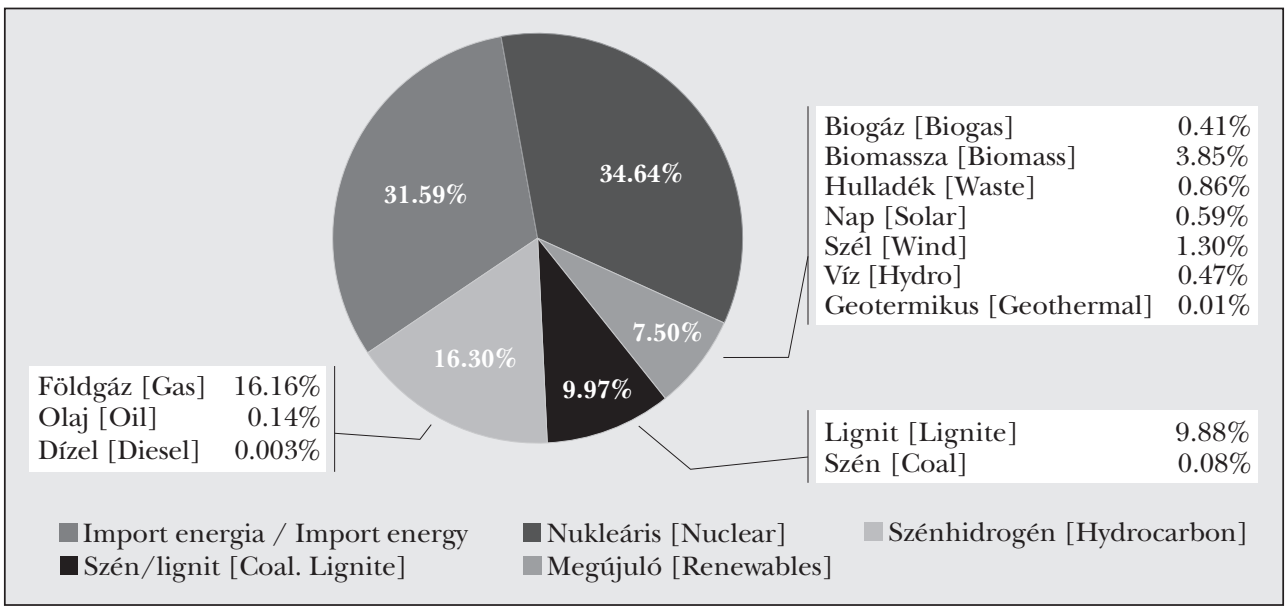

Source: Mavir, 2019

Decarbonisation also involves the exploitation of renewable energy sources. Hungary has committed to raise the ratio of renewables to gross domestic product to $20 \%$ by 2030 . In the field of electricity generation, the competent ministry is planning to expand the current capacity of nearly $1200 \mathrm{MWp}$ of solar power to about $7000 \mathrm{MWp}$ of installed solar power by 2040. Within this, the share of residential production may increase from the current $400 \mathrm{MWp}$ to $1500 \mathrm{MWp}$. This degree of decentralised renewable expansion will necessarily bring about the development of electricity networks and their resilience.

Chart 10: Forecast renewable electricity generation (GWh), incl. the RES-E ratio (\%)

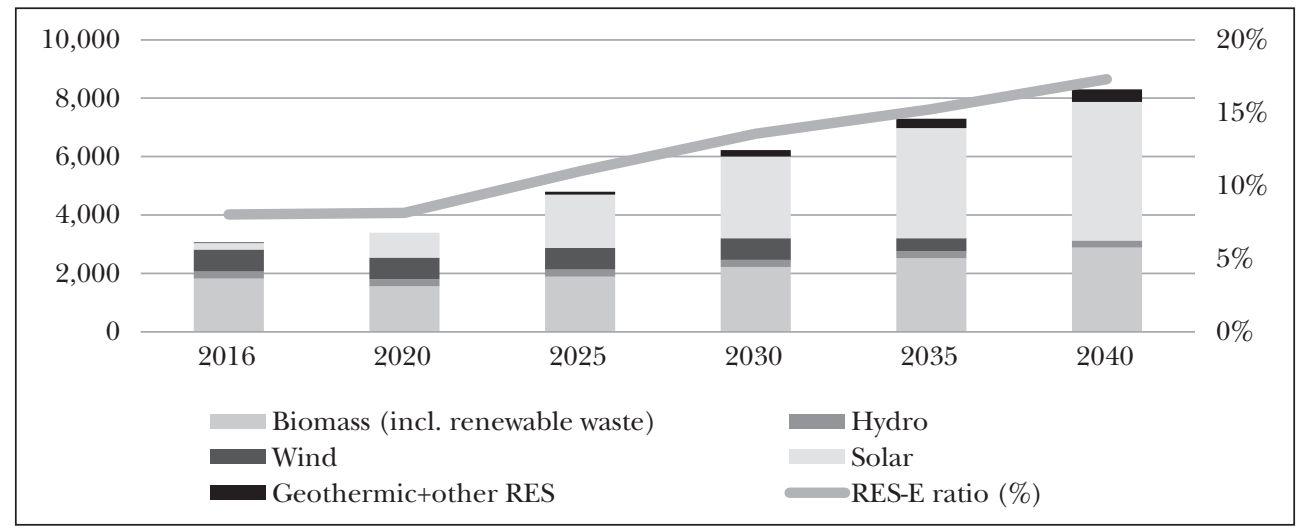

Source: Ministry for Innovation and Technology, 2020 
The use of nuclear energy is indispensable for the achievement of the Hungarian energy policy goals.

The Paks Nuclear Power Plant produces the cheapest and cleanest electricity in the Hungarian power generation structure. The security of supply is guaranteed by an average power utilisation rate of over $90 \%$ per annum and a sufficient supply of strategic fuel for 2 years. In a nuclear power plant, the cost of fuel is about $15 \%$ of the cost of the generated electricity, i.e. a change in the price of nuclear fuel has little effect on the price of electricity produced. As, however, the licensing and provisioning process of nuclear power plants is rather long, replacement of the current capacity, approaching the end of its life cycle, must be resolved as soon as possible by the construction of Paks 2 (Ministry of National Development, 2012).

Chart 11: Forecast GHG emission by the energy sector, incl. the impact of the current policy measures ( $k t \mathrm{CO} 2 e q)$.

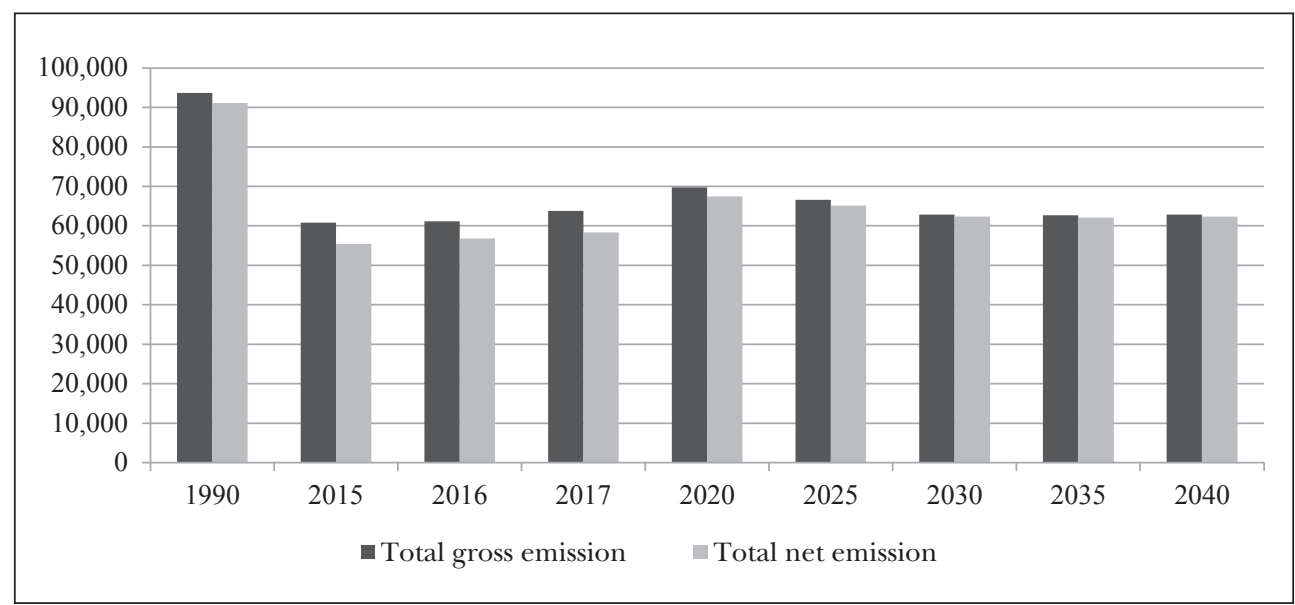

Source: Ministry for Innovation and Technology, 2020

The competent ministry also intends to involve consumers in carbon-free production using renewable sources, encouraging them to meet their own energy needs, possibly using their own storage capacity and smart devices, thus contributing to the stability of the electricity system. The merger of 'producer' and 'consumer' activities will thus lead to the emergence of the 'prosumer', the active user.

The main elements of the new energy strategy concept are as follows:

- Placing the consumer at the heart of the energy strategy,

- Ensuring the sustainability of utility cuts,

- Improving the security of supply and increasing the use of resources located in Hungary,

- Climate-friendly transformation of the energy sector,

- Encouraging energy innovation for carbon neutrality, including smart technologies, energy storage, etc. 
- The government gives priority to domestic solar energy utilisation: it supports the installation of small-scale household power plants. Small and medium-sized enterprises provide their own energy supply from renewable sources and promote the development of cost-effective renewable power plants on an industrial scale.

Industrial scale power plants with a rated capacity of $50 \mathrm{MW}$ or more require a production license for the generation of electricity. Above the threshold of $0.5 \mathrm{MW}$ nominal power, a combined power plant license is sufficient (Szuchy, 2018).

\section{Hungarian Energy Strategy 2030 , WITH AN OUTLOOK UNTIL 2040}

The Hungarian Energy Strategy 2030 completed in 2011 was made to become the foundation document of the domestic energy policy. As part of the European Union, Hungary has to take part in accomplishing the actual EU energy strategy. The changes of the past decade and new European trends have made the upgrading of the Hungarian Energy Strategy 2030 inevitable. The document was adopted on 19 January 2020, as a result of several years of preparatory work. Its major objectives are creating energy independence in parallel with maintaining the security of supply, as well as decarbonisation while retaining energy consumption cost reduction. In the year 2019, the ratio of imported electric energy use in total domestic electric energy consumption was $27,56 \%$, which is equal to 12,59 TWh (Mavir, 2020). To accomplish those objectives, the ministry in charge plans to upkeep nuclear energy production capacity and increase renewablebased energy production. A considerable growth of renewables is expected through utilizing solar energy. Among other renewable energy sources, there are further potentials for capacity growth in the use of biomass, biogas, water energy and geothermal energy with the application of novel technologies. Innovation must play a major role in this, which is a factor that is especially in the focal point of energy policy. Innovative solutions may help the spread of decentralised solar power stations. The new production structure dissimilar to the present one together with novel energy flow directions will generate transformations in the system of electrical power grid. The significant increase of weather-dependent producers will necessitate the development of flexibility capacity. This means the establishment of modern energy power reservoirs and additions the existing gas turbine range. It is practical to substitute the withdrawing coal-fired generator Mátra Power Plant with technologies facilitating the resiliency of the power grid. The system security of the upgraded production structure and the enhancement of energy efficiency puts the application of smart solutions to the foreground.

To provide for our continuously growing energy need, Paks Nuclear Power Plant plays an indispensable role. Almost half of the energy production in 2019 was provided by the nuclear power station. The extended operating time valid today will expire between 2032 and 2037 in case of all four blocks.

The investment in Paks 2 capacity maintenance is an essential condition to secure energy provision and to produce 90 percent carbon-neutral electric energy that Hungary has made a commitment to. 
Chart 12: The structure of domestic electric energy production in 2019

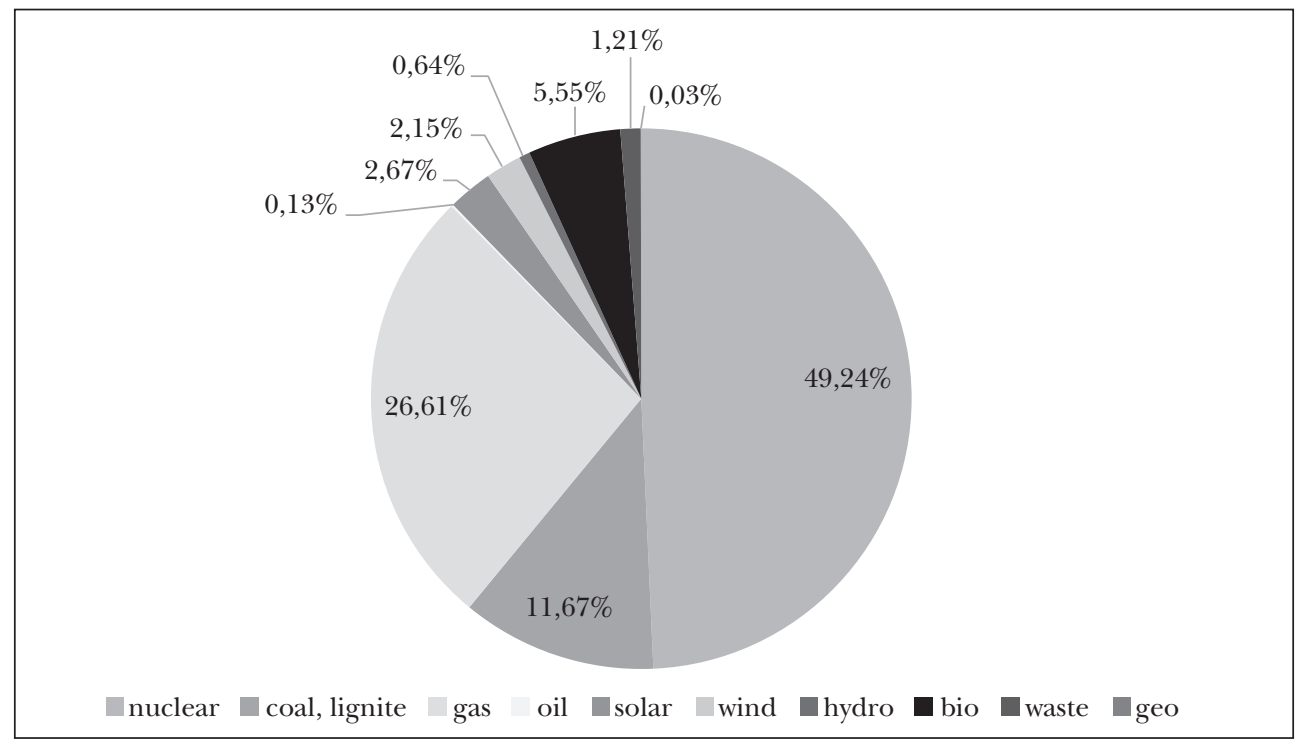

Source: Mavir, 2020

For Hungary, it would mean an extra expenditure of 50.000 billion Hungarian forints to achieve full climate neutrality that the European Union expects all member states to implement by 2050 .

The following is a short summary of the objectives of the most recently approved national energy strategy expressed in numbers.

32,5 percent of our ultimate energy consumption is based on natural gas. 80 percent of our natural gas need come from import. Due to energy efficiency measures, the introduction of biogas and Renewable District Heating Program, and the transformation of electric energy production structure, the planned proportion of natural gas import will reduce to 70\%. By 2040, it will fall below 70\%. Between 2013 and 2017, our import energy consumption was $32 \%$ on average. As a consequence of expansion in nuclear energy and the incentive for renewable-based production, domestic production proportion will reach $80 \%$ by 2040 , according to the plans of the ministry in charge. $90 \%$ of production is expected to be carbon-neutral already by 2030 . A portfolio of more than 6.000 MW solar power station targeted for 2030 is anticipated to rise to $12.000 \mathrm{MW}$ by the document of the Hungarian Energy Strategy. A crucial element of the programme is that the energy produced in a decentralized way must be used in the area of production. By 2030, the proportion of renewable energy consumption will be a minimum of $21 \%$ of the ultimate energy consumption. Our emission of greenhouse gases will reduce to 40 percent of the figure in 1990 by the year 2030 .

The Committee of Energetics Innovations puts special emphasis on nuclear innovation besides system balance, energy efficiency and renewable-based production. Apart from gaining more experiences in the field of nuclear energy, further plans 
include the establishment of Fuel Rod Laboratory, a Nuclear Decommissioning, Materials Science, Radioactive Waste Management Centre for Learning and Paks 2 Virtual Training and Practice Centre.

Innovation development works have a significance beyond their technical and economic effect, expanding employment and common knowledge equally.

\section{PRIMARY RESEARCH}

\section{Methodological background}

A nationwide survey was conducted by quantitative research between October 2018 and April 2019, and over 300 people were asked. The questionnaire was dispatched electronically. Uniform evaluation based on identical bases was ensured by response options provided next to the closed questions in the questionnaire, which was drafted coherently in content and form. Efforts were made at wording the questions without offending the feelings or the privacy of the potential respondents. Particular attention was also paid to not reducing respondents' willingness to answer, and rather, to ask questions that arouse their interest in the topic. It was also important to conduct research in a field not yet surveyed on a national scale: the awareness of the general public of the individual energy sources, their benefits and potential risks. 287 online questionnaires sent by e-mail were completed fully and correctly. For the analysis of the database collected on the online interface, statistical data sorting was performed by SPSS 21 (Statistical Package for Social Sciences).

The responses were evaluated on the basis of the cross tables generated by the SPSS 21 software. Perhaps due to the nature of the topic, the vast majority of the respondents were men: 224 men and 63 women completed the questionnaire.

\section{Chart 13: Distribution of respondents by gender}

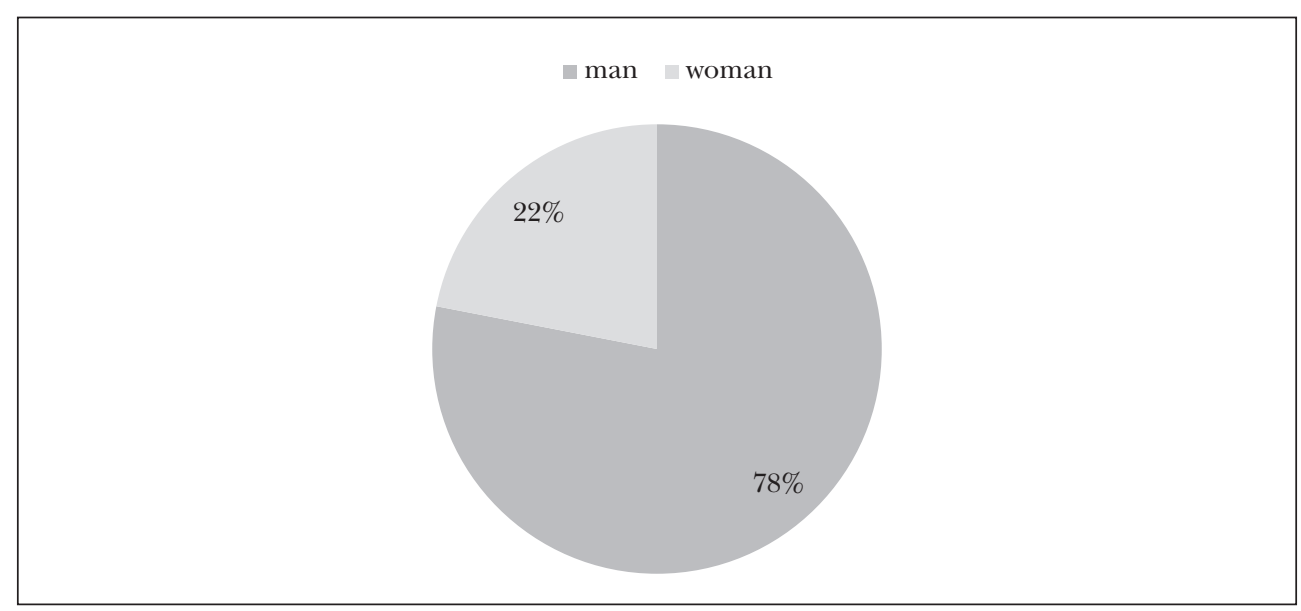

Source: Author's own research, 2019, $N=287$ 
A breakdown by age group shows the highest representation in Generation Y. Generations $\mathrm{BB}$ and $\mathrm{X}$ contributed almost equally to the questionnaire. Due to their low number, the respondents born before 1946 (2 persons) or after 2000 (7 persons) cannot be considered relevant. The eldest generation is likely to have difficulties managing the online interface, while the youngest ones may not be interested enough in the topic. It is promising that the 7 respondents of the generation born after 2000 already feel it important to support research. In what follows, focus is on the generations significantly represented in the survey.

Chart 14: Distribution of respondents by age

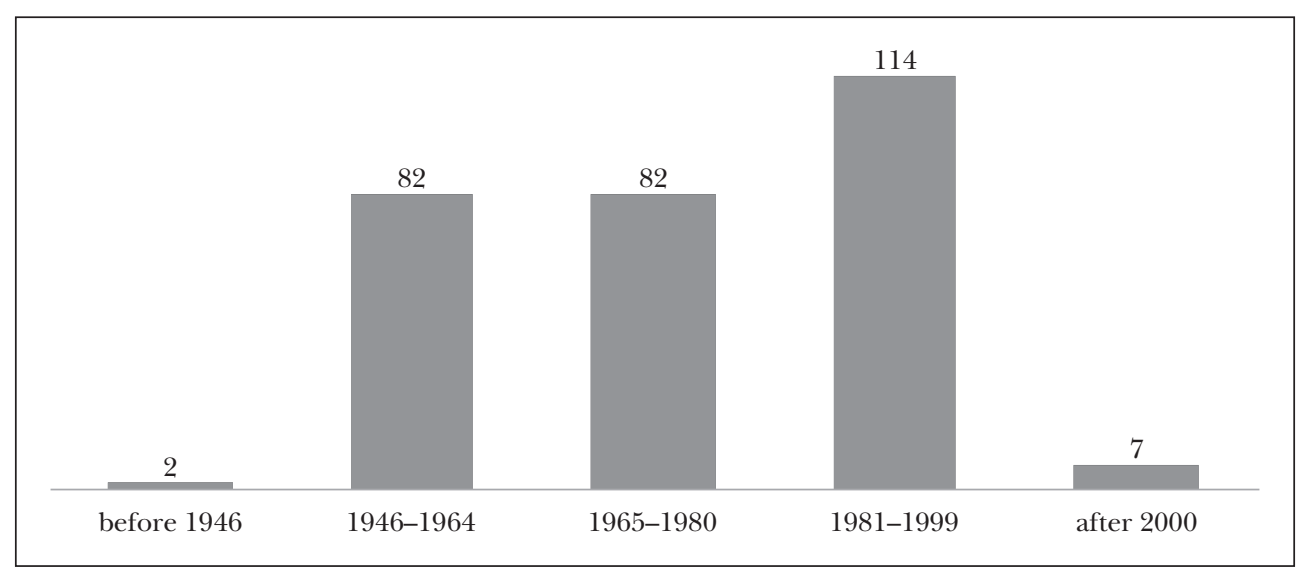

Source: Author's own research, 2019, $N=287$

In a breakdown by qualifications, the number of returned questionnaires is proportional to increase in the level of education: the ratio of university graduates was the highest among the respondents. Respondents with only primary education are likely to be predominantly from the youngest age group.

Chart 15: Distribution of respondents by qualification

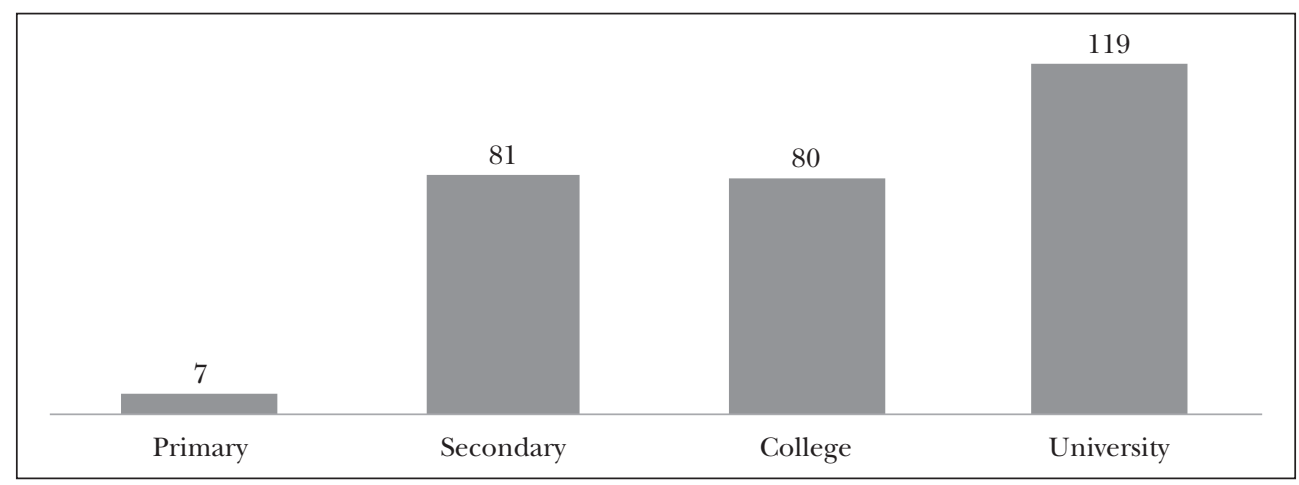

Source: Author's own research, 2019, $N=287$ 


\section{FINDINGS}

One of the questions asked during the research concerned the importance using coal, lignite and natural gas in the production of electricity. The answers were analysed according to the ages of the respondents and the following results were obtained with the help of an SPSS program cross-table.

\section{Chart 16: Assessment of the importance of coal, lignite and natural gas in Hungarian} electricity generation by the age distribution of respondents

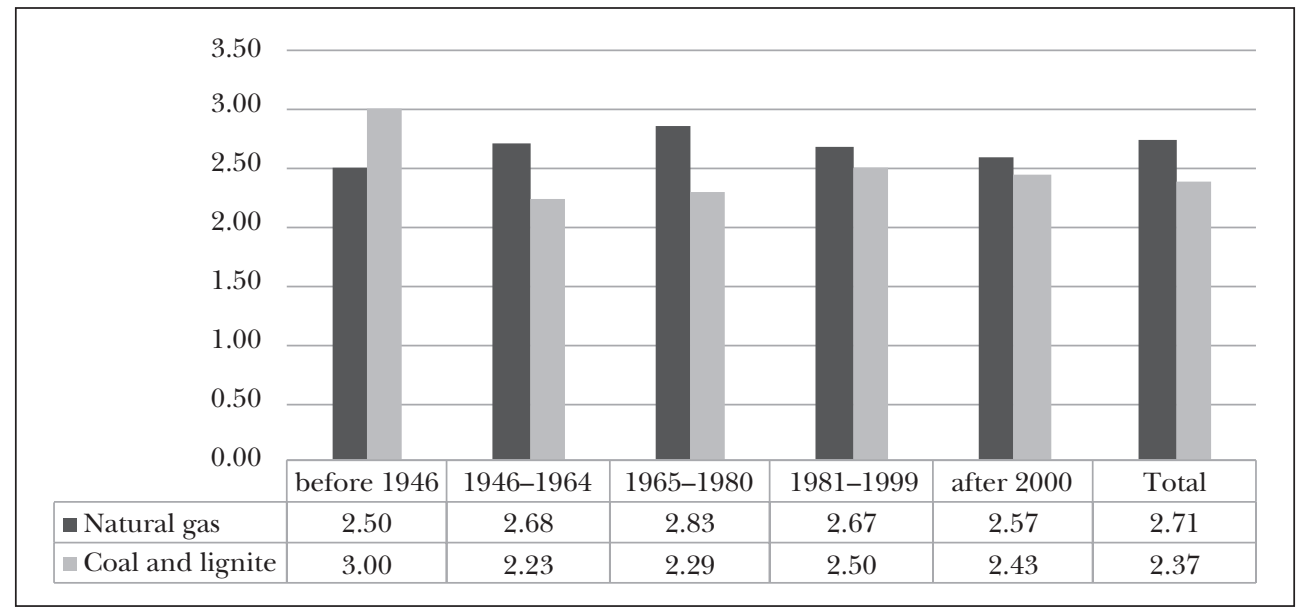

Source: The author's own research, 2019, $N=287$

Respondents born between 1946 and 1999 rated the importance of coal, lignite, and natural gas at a weighted average below 3. The Hungarian electricity system is currently compelled to import more than $30 \%$ of the required energy. If almost $20 \%$ share in fossil fuels disappeared from the domestic production system, import dependency would further increase, which would pose a much greater risk than the current low electricity prices and the continuity of supply. Coal blocks could be replaced by nuclear technology to perform basic power-plant tasks, and the Paks 2 power plant under construction will be suitable for this purpose. Therefore, it can be stated that this production segment will definitely remain operative in the short term. Over the long term, with the expansion of weather-dependent renewables, even despite the emergence of industrial-scale energy storage, the capacity of gas turbines need to be expanded to ensure network resilience.

Hungary emits more than 66 million tonnes of carbon dioxide a year, and over $70 \%$ of this amount comes from fossil fuels. The next question was whether respondents saw any relationship between natural gas-based and coal-based electricity generation and greenhouse gas emission. In addition, respondents were asked if they saw a relationship between greenhouse gas emission (CO2 and methane) and climate change. 
Chart 17: Contribution of coal, lignite and natural gas to the greenhouse effect and to climate change. Responses by age distribution

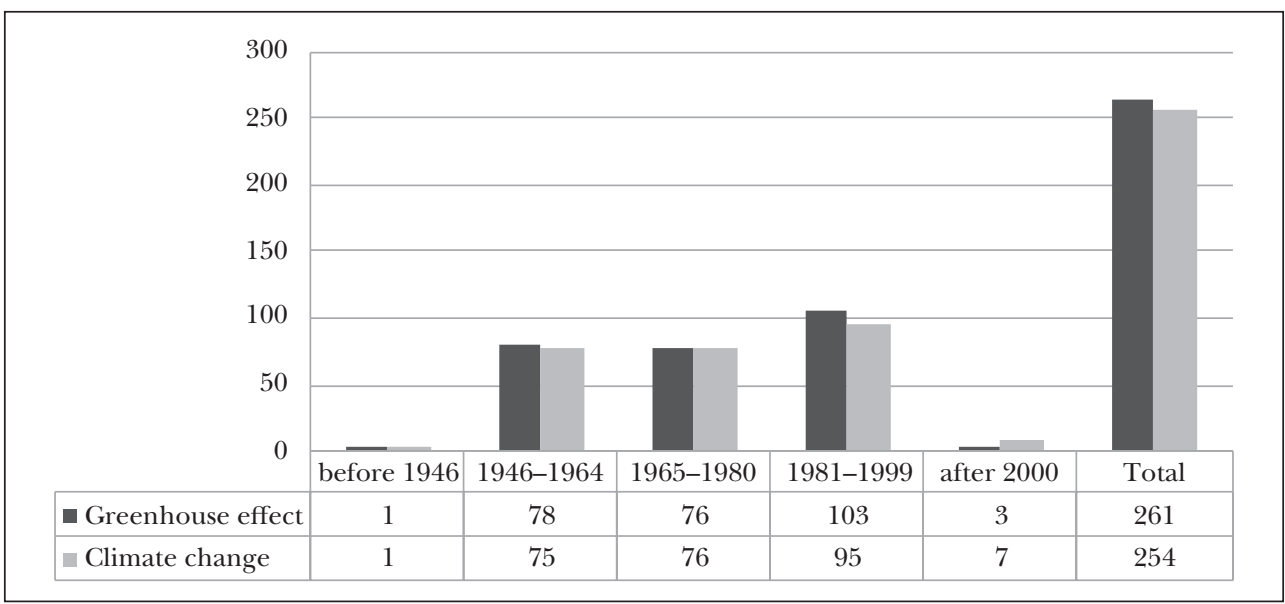

Source: Own research, 2019, $N=287$

Respondents were given the options "yes", “no" and "don't know". In all the three generations that could be taken into account for the evaluation, over $90 \%$ of the respective age group thought that there was a correlation between natural gas-based and coalbased electricity production and greenhouse gas emission. $90.4 \%$ of the respondents born between 1981 and 1999, representing the largest sample, responded affirmatively, and this ratio is nearly $5 \%$ less than the ratio of those who answered affirmatively the generation born between 1946 and 1964. This is due to the fact that $7 \%$ of the younger age group expressed their uncertainty about this topic by checking the answer "don't know". The vast majority of respondents identify the greenhouse effect as a consequence of carbon dioxide emissions, causing climate change. While more than $90 \%$ of those born between 1946 and 1980 presumed a correlation between greenhouse gas emission and climate change within their age group, only $83.3 \%$ of the younger generation shared the same view. Within the latter age group, the ratio of uncertainty about the question remained virtually unchanged in comparison to the previous question, but almost $9 \%$ of them believe there is no correlation. Globally, electricity generation accounts for more than $30 \%$ of the total amount of emitted carbon dioxide. As electricity demand is increasing both internationally and in Hungary, only a change in the structure of production by power plants or energy-conscious use can result in reduction in carbon emissions.

Carbon-free technologies should be prioritised during a reform of the power generation structure. Improvement may start in the production of either renewable or nuclear energy. In 2016, the renewable sector accounted for nearly $9 \%$ of Hungary's electricity production, while nuclear power accounted for $51.6 \%$.

Decentralised small power plants, as weather-dependent producers using renewables, are unsuitable for replacing the continuously available basic power plants. In order to meet the ever-present demand for power on the consumer side, power plants 
generate a steady supply of large and cheap electricity. Only coal-fuelled power plants and nuclear power plants converting fissionable materials are suitable for performing basic power plant functions. Although these technologies require considerable installation work and high investment costs, but are crucial for the economy. Project financing, as a special form of credit, helps to cover the high set-up costs (CsiszárikKocsir, 2016a; Csiszárik-Kocsir and Molnár, 2019). Due to the high risk of project financing as a structured credit market product, banks are only willing to enter the financing side after careful consideration, proactively monitoring the situation and looking for the indications of financial markets (Csiszárik-Kocsir, 2016b). For this very reason, life span is an important factor in their profitability. One of the questions in the dispatched questionnaire was the expected lifetime of the Paks Nuclear Power Plant.

Chart 18: Planned lifetime of the Paks Nuclear Power Plant by the respondents' age distribution

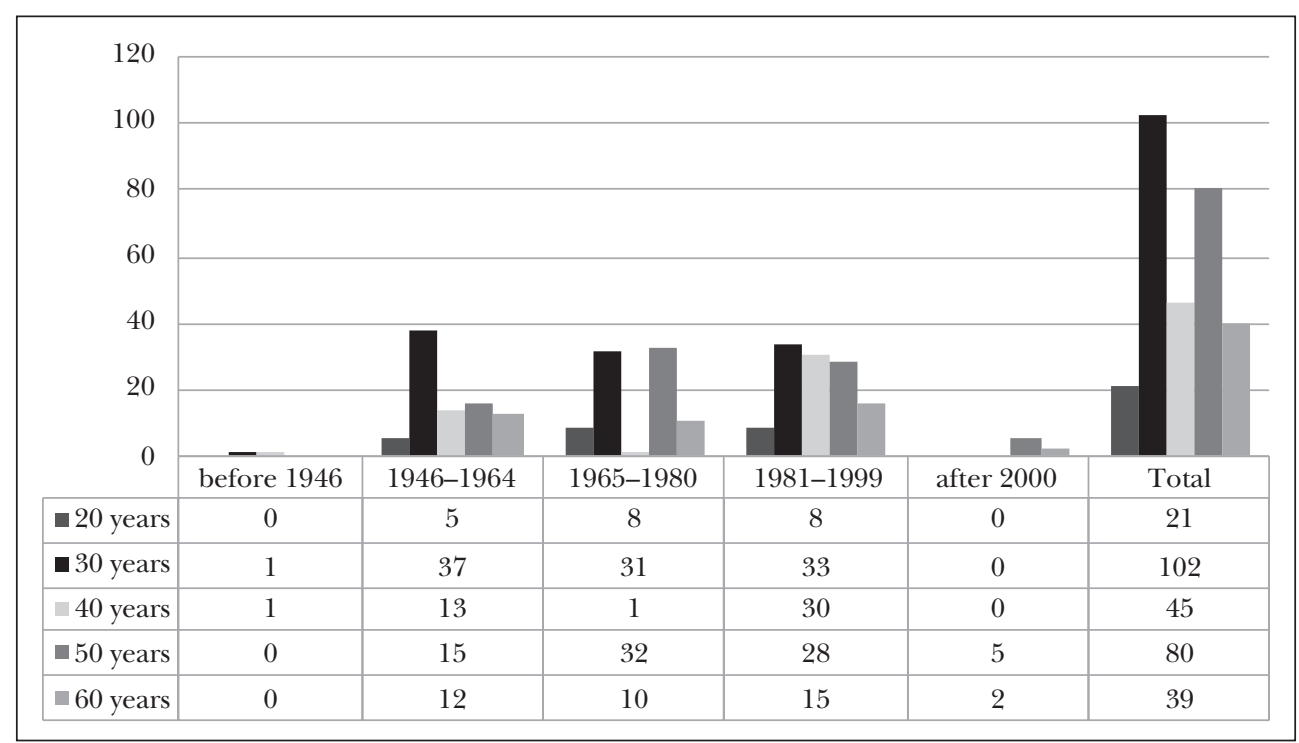

Source: Author's own research, 2019, $N=287$

Respondents were given five predefined lifetime options to choose from. The largest consensus between the various generations was concerning the 30-year lifespan: $35.5 \%$ of all respondents chose this response. This was also the most popular within the age bracket, i.e. in the generation BB: $45.1 \%$ opted for it. The other term that may be considered significant was the 50 -year life span, chosen by $27.9 \%$ of all the respondents. The largest consensus about operation planned for 50 years was recorded in generation $\mathrm{X}$, with $39 \%$.

The plant was originally designed for 30 years, and its four blocks expired one after the other: in 2012, 2013, 2016 and 2017. Thanks to successful life extension projects, each unit can continue production for an additional 20 years. 
The Paks Nuclear Power Plant is scheduled to be shut down between 2032 and 2037, and the missing capacity will need to be replaced. To this end, the Hungarian government has launched the Paks 2 project. The new facility will comprise two units of generation 3+, with a capacity of 1200MW each. Generation 3+ nuclear technology uses passive systems and offers increased security and regulatory flexibility.

The next question concerned the planned lifetime of the Paks 2 Nuclear Power Plant.

Chart 19: Planned lifetime of the Paks 2 Nuclear Power Plant, in a breakdown by the respondents' ages

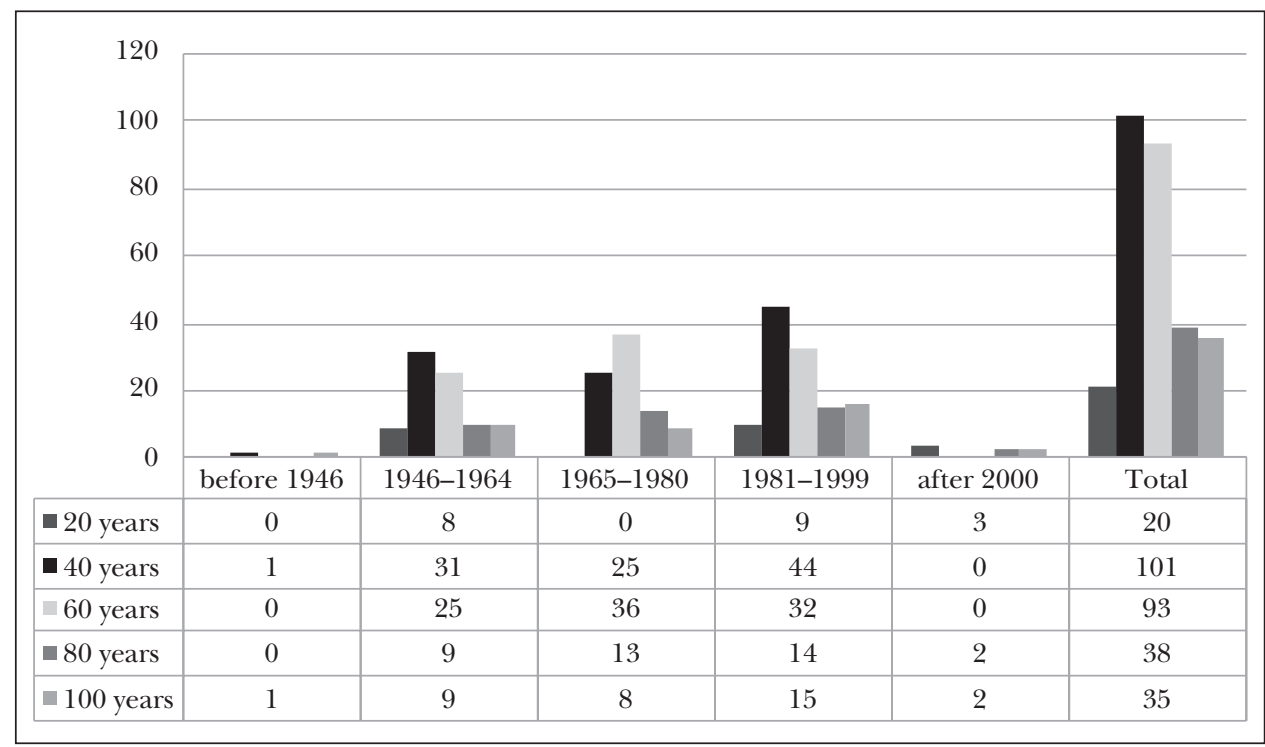

Source: Author's own research

$35.2 \%$ of all the respondents opted for 40 years. $40.6 \%$ of the respondents in Generation $\mathrm{Y}$ thought that the planned life expectancy was 40 years. A 60- year life-span was predicted by $32.4 \%$ of all the respondents. The largest consensus, i.e. $43.9 \%$, was shown in generation X. The new blocks are actually planned for 60 years. Based on the international experience in nuclear power plants beyond their originally planned lifetimes, a review of the units after 60 years will probably allow operation to continue. Taking utmost account of climate protection and the security of supply, the option of further nuclear capacity expansion would be worth exploring.

\section{SUMMARY AND CONCLUSIONS}

Since the dawn of history, people have been using energy to survive. By now, the amount of energy consumed per person has multiplied and is constantly increasing. The continuous availability of energy is a basic condition for the functioning of hu- 
man societies. If exploitation of the Earth's energy resources and goods continues at the current rate, this could easily lead to the end of human civilisation.

In 2040, mankind will be consuming over $25 \%$ more energy than currently. The consumption and emission growth rates increase fastest in India and Asia, where the current energy use will have doubled by 2040 . Hungary also has a significant development potential in energy management. Energy intensity, or energy consumption to per capita GDP, is more than twice the average of Western European countries. Having adopted the European Union's energy and climate protection policy, Hungary has voluntarily made stricter commitments than required by the EU. These include increasing the use of renewables and reducing greenhouse gas emissions. In 2018, the Ministry of Innovation and Technology prepared Hungary's National Energy and Climate Plan in preparation for the new Hungarian energy strategy.

The use of clean energies, energy efficiency and energy saving in all segments of the economy and society, and consistent adherence to them are the keys to the sustainability of life on Earth. Not using energy is the best way to protect our environment and our future. Sustainability means that we retain the opportunity for future generations to shape their living conditions. The most important element in climate protection and the fight against global warming and environmental pollution is man himself. The conscious or responsible lifestyle of individuals can be one of the most effective means of reducing the human activity that is destroying the Earth, and it is also essential in slowing down the rate of warming. One of the most important tools for developing an energy and environmentally conscious lifestyle is shaping attitudes at all levels of society. In all areas of education, education from kindergarten to university education, it is necessary to introduce environmental.

Policy-prepared climate protection measures could have a positive impact on the development of domestic small and medium-sized enterprises.

One of the objectives of the new Hungarian energy strategy is to keep energy prices low and predictable, which is a win-win situation for all economic players. On the other hand, the large-scale nuclear and renewable-based power plant projects envisaged in the government strategy also represent new business areas for SMEs. They have the opportunity to do business with multinational companies and in niche markets on their own. SMEs flexibility and expertise in innovation, development, design and construction is a need. Specialised companies will be able to use the knowledge and experience gained in the implementation of domestic projects in the international market.

The purpose of my primary research, conducted through a nationwide survey, was to assess the population's awareness and opinion about the availability and use of different energy sources, their risks, the consequences of their use, and the need for additional activities related to them. An analysis and evaluation of the responses led to the following main conclusions: Willingness to respond increased in proportion to increase in qualification, with the largest sample provided by university graduates. Respondents born between 1981 and 1999 were the most active. However, the majority of respondents are adequately informed, and the remaining uncertainties highlight 
the need for attitude formation at all ages. It is encouraging that seven people of the youngest age group have already found it important to assist research with their answers. Personal feedback from the respondents suggests that many people have tried to look for possible good answers when completing the questionnaire. On the one hand, this is due to the relatively high level of knowledge. The other important message is that it is important for respondents to be prepared for the topic, which is why their lack of knowledge and insecurity encouraged them to learn about it.

Pre-defined response options can also play an important role in choosing the right answers. A further breakdown or shading of each answer would probably have made the answers more selective. Furthermore, the relatively good result can be explained by the fact that the respondents were internet users. They are the ones who regularly surf the sea of information and so they were likely to find it important to be open or possibly committed to the topic, and to spend time for and effort at responding.

The results suggest that there is a need for continuous awareness-raising in all age groups and social groups. Topics should include energy saving, energy efficiency, pollution, the benefits and impacts of renewable energy sources, a full demonstration of the use of nuclear energy, and the environmentally responsible use of energy. Awareness-raising can be genuinely effective the level of the population's knowledge is continuously and accurately measured.

\section{RefERENGES}

Bloomberg (2017): New Energy Outlook 2017. Bloomberg New Energy Finance.

Borzán, A. and Szekeres, B. (2017): A hazai és a román környezeti költséggazdálkodás fontosabb jellemzôinek vizsgálata [Analysis of the key features of environmental budgeting in Hungary and in Romania]. Számviteli Tanácsadó, Vol. 9, No. 9, pp. 2-9.

British Petrol (2019): BP Energy Outlook. www.bp.com/content/dam/bp/business-sites/en/global/corporate/pdfs/energy-economics/energy-outlook/bp-energy-outlook-2019.pdf (accessed 13 April 2019).

Capros, P.; Kannavou, M.; Evangelopoulou, S.; Petropoulos, A.; Siskos, P.; Tasios, N.; Zazias, G. and DeVita, A. (2018): Outlook of the EU Energy System Up to 2050: The Case of Scenarios Prepared for European Commission's “Clean Energy for All Europeans” Package Using the PRIMES Model. Energy Strategy Reviews, Vol. 22, pp. 255-263, https://doi.org/10.1016/j.esr.2018.06.009.

Csiszárik-Kocsir, Á. (2016a): A megújuló energiaforrások projektfinanszírozása a 2005 és 2015 között végrehajtott tranzakciók alapján. Journal of Central European Green Innovation, Vol. 4, No. 3, pp. 127-141, https://doi.org/10.22004/ag.econ.253391

Csiszárik-Kocsir, Á. (2016b): A nemzetközi és az európai projektfinanszírozási piac átalakulása a válság hatására [Developments in international and European project financing as a result of the crisis]. Hitelintézeti Szemle, Vol. 15, No. 1, pp. 51-69.

Csiszárik-Kocsir, Á. and Molnár, F. (2019): Energiaigény és projektfinanszírozás - prioritások a múltban és most [Energy demand and project financing - priorities past and present]. In: Koltai, L. (ed.): Hazai és külföldi modellek a projektoktatásban [Project training models in Hungary and abroad]. Scientific Conference Proceedings, University of Óbuda, Rejtô Sándor Faculty of Light Industry and Environmental Engineering, pp. 415-422.

European Commission (2016a): Clean Energy for All Europeans. European Commission, COM/2016/0860 final.

European Commission (2016b): Proposal for a Regulation of the European Parliament and of the Council on binding annual greenhouse gas emission reductions by Member States from 2021 to 2030 for a resilient 


\section{Ferenc Molnár: The Role of Electricity in Sustainable Energy Supply}

Energy Union... COM(2016) 482 final, https://eur-lex.europa.eu/resource.html?uri=cellar:923ae85f5018-11e6-89bd-01aa75ed71a1.0002.02/DOC_1\&format=PDF.

European Council (2014): Conclusions. Special meeting of the European Council (16 July 2014), EUCO $147 / 14$, pp. 1-6.

Hejazi, R. (2017): Nuclear Energy: Sense or Nonsense for Environmental Challenges Science Direct. International Journal of Sustainable Built Environment, Vol. 6, No. 2, pp. 693-700, https://doi.org/10.1016/j. ijsbe.2017.07.006.

IEA (2010): World Energy Outlook 2010. International Energy Agency, https://doi.org/10.1787/weo-2010en.

IEA (2018): World Energy Outlook 2018. International Energy Agency, https://doi.org/10.1787/weo-2018en.

Intergovernmental Panel on Climate Change (IPCC) (2014): Climate Change 2014: Synthesis Report. IPCC, Geneva.

Intergovernmental Panel on Climate Change (IPCC) (2000): Special Report on Emission Scenarios (SRES). Cambridge University Press, Cambridge.

Járosi, M. (2018): Az ellátásbiztonság energiapolitikája. Polgári Szemle, Vol. 14, No. 4-6, pp. 15-31, https:// doi.org/10.24307/psz.2018.1203.

Mavir (2019): A Magyar Villamosenergia-rendszer adatai, 2018 [Data of the Hungarian electricity system]. Mavir Zrt., www.dropbox.com/s/280pt9dhq2vgj1j/MAVIR_VER_2018.pdf?dl=0.

Mavir (2020): A Magyar Villamosenergia-rendszer elôzetes adatai, 2019 [Preliminary data of the Hungarian electricity system]. Mavir Zrt.

Ministry for Innovation and Technology (2018): Hungary's National Energy and Climate Plan.

Ministry for Innovation and Technology (2020): Hungary's National Energy and Climate Plan.

Ministry of National Development, State Secretariate for Climate and Energy (2012): National Energy Strategy 2030.

Pintér, T. (2015): Integrált városfejlesztés az Európai Unió keleti és nyugati tagállamaiban - Románia és Németország esete. Journal of Central European Green Innovation, Vol. 3. No. 2, pp. 123-136.

Portfolio. hu (2019): Megmagyarázta a kormány, miért vétózta meg a klímavédelmi alkut. [The government explained why it had vetoed the climate deal]. Portfolio. hu, www.portfolio.hu/gazdasag/zoldvilag/megmagyarazta-a-kormany-miert-vetozta-meg-a-klimavedelmi-alkut.328633.html (acessed 1 August 2019).

REN21 (2018): Renewables 2018 Global Status Report. Renewable Energy Policy Network for the 21th Century, Paris.

Szuchy, R. (2018): A magyar energiaszabályozás kezdetei, különös tekintettel a villamosenergia-piacra [The Beginnings of Energy Regulation in Hungary, with Special Focus on the Electricity Market]. Polgári Szemle, Vol. 14, No. 4-6, pp. 79-87, https://doi.org/10.24307/psz.2018.1206.

Tashimo, M. and Matsui, K. (2008): Role of Nuclear Energy in Environment, Economy, and Energy Issues of the 21st Century - Growing Energy Demand in Asia and Role of Nuclear. Progress in Nuclear Energy, Vol. 50, No. 2-6, pp. 103-108, https://doi.org/10.1016/j.pnucene.2007.10.024. 